\title{
SOD2 Gene
}

National Cancer Institute

\section{Source}

National Cancer Institute. SOD2 Gene. NCI Thesaurus. Code C39642.

This gene is involved in the detoxification of superoxide radicals produced within mitochondria. 